$A D D I N$, Volume 12, Number 1, February 2018

\title{
MORAL AND SCIENCE INTEGRATION IN THE QUR'ANIC EDUCATION PERSPECTIVE
}

\author{
M. Asy'ari \\ IAIN Palu, Central Sulawesi, Indonesia \\ asyari1204@gmail.com
}

\section{Abstract}

Education is very important factor for bumans because it can determine the progress of a nation. Men are not only directed to the increase of knowledge, but also moral. In the concept of Islam, education and teaching must integrate the science and morals. The approach used by the Qur'an in educating and teaching bumanity is to achieve balance and harmony symbolized by hasanah fi ad-dunya wa hasanah fi alakbirah. After a man worship God sincerely, he is burdened with education and teaching related to educating, teaching and guiding his soul, such as obeying parents, respecting for the elder, loving the younger and so forth. It is intended by the Qur'an that man is always holy and keep the holiness that God gives. While the power of human thought is directed to read, analyze and conclude the signs of God's greatness. In such circumstances, the Qur'an will be able to give direction, educate and teach people to the path of ultimate life happiness.

Keyword: Integration, Moral, Science, Qur'anic Education. 


\section{Abstrak}

INTEGRASI MORAL DAN ILMU DALAM PERSPEKTIF PENDIDIKAN QUR'ANI. Pendidikan merupakan faktor yang sangat penting bagi manusia, karena dapat menentukan kemajuan suatu bangsa. Manusia tidak banya diarabkan kepada peningkatan pengetahuan, tetapi juga moral atau akblak. Dalam konsep Islam, pendidikan dan pengajaran harus terintegrasi antara ilmu dan moral. Pendekatan yang digunakan alQur'an dalam mendidik dan mengajar manusia adalah agar mencapai keseimbangan dan keharmonisan yang dilambangkan dengan hasanah fi ad-dunya wa hasanah fi al-akbirah. Setelah manusia ikblas menyembah-Nya, maka dibebani dengan pendidikan dan pengajaran yang berkaitan dengan mendidik, mengajar, dan membimbing jiwanya, seperti mematubi orang tua, menghormati yang lebih tua, menyayangi yang lebih muda, dan lain sebagainya. Hal ini dimaksudkan oleh alQur'an agar manusia selalu suci dan menjaga kesucian yang Allah berikan. Adapun daya pikir manusia diarabkan untuk membaca dan menganalisis serta menyimpulkan isyarat serta tanda-tanda kebesaran Allah. Dalam situasi dan kondisi begaimanapun, alQur'an akan mampu memberikan arah, mendidik dan mengajar manusia ke jalan kebahagiaan hidup yang hakiki.

Kata Kunci: Integrasi, Moral, Ilmu, Pendidikan Qur'ani.

\section{A. Introduction}

Education is very important factor for humans because it determines the progress of a nation. Therefore, for humans, it is not only directed to increase the knowledge, but also the moral. These two things cannot be separated because if there is an imbalance in education and teaching, there will be chaos and disharmony in the life of humanity. To achieve such thing, there are no theorythat integrates education and teaching, except those in the concept of Islam in the Qur'an. In the concept of Islam, education and teaching must be integrated between science and morals. 
Education and teaching in the concept of Islam refers to all practices carried out by the Prophet Muhammad which are based on the Qur'an. The approach used by the Qur'an in educating and teaching humans is to achieve balance and harmony symbolized by hasanah fi ad-dunya wa hasanah fi alakhirah. Humans have the driving energy that is called the willingness so the power of human willingness is directed by the Qur'an to reach the level of being able to maintain the sanctity of self to Allah by guiding and directing people to the path that God wants.

After people sincerely worship Him, then they are burdened with education and teaching related to educating, teaching and guiding their souls, such as obeying parents, respecting older people, caring for younger ones and so on. This is intended by the Qur'an so that humans are always holy and maintain the sanctity that God gives.

The human thinking power is directed to read, analyze and conclude the signs of God's greatness. In any situation and condition, the Qur'an will be able to direct, educate and teach people to the true path of life happiness. This research elaborates the techniques, strategies and methods of the Prophet Muhammad and other educational figures in educating future generations. The results of this study are expected to be the basis for the application of appropriate methods for education and teaching in order to prepare the next generation who are knowledgeable, intelligent, trustworthy and noble.

\section{B. Discussion}

\section{Definition of Islamic Education}

In the first International Conference on Islamic education, «First World Conference on Moeslim Education» which was held by King Abdul Aziz University in 1977, 
according to Islam, education is the whole understanding in the term "ta'lim, tarbiyab, and ta'dib". According to Syeid Muhammad al-Naquib al-Attas argued, the term "ta'dib" is the most appropriate to describe the notion of education in Islam. The term "ta'lim" is too narrow because it only shows the understanding of teaching. While the term tarbiyah is too broad because this term includes the notion of education for animals. Furthermore, he explained that the term "ta'dib" is a model of verb or fi'il "addaba" which means education, from the word "addaba" which is also derived from the word "adabun". According to al-Attas, "adabun" means the recognition of the nature that knowledge and existence are hierarchically organized according to their various levels and degrees, and about one's proper place in relation to that nature and physical capacity and potential, intellectual or someone's spirit. Based on the understanding of adab, alAttas defines education is as an introduction and recognition that is gradually instilled in humans about the right place in all things of this form so that it leads to the introduction and recognition of the right place of God in that existence. ${ }^{1}$

This definition puts God as the most appropriate and important part in education, so based on this understanding, the most important goal of education is to know and acknowledge God's place in this form of existence. The understanding of more operational Islamic education is proposed by Marimba. She said that Islamic education is physical and spiritual guidance based on Islamic law towards the formation of a main personality according to Islamic standards. Personality that is in accordance with the Islamic values is clear and based on the values in the Qur'an as holy book that provide essential instructions in education. In the

${ }^{1}$ Muhammad Naquib al-Attas, Konsep Pendidikan dalam Islam, terj. Haidar Bagir (Bandung: Mizan, 1984), 52. 
Qur'an, God commands to always learn. It is understandable that learning as a source of knowledge "al- ilm" really needs to be owned by Muslims. Surat al-'Alaq implies that humans must be good at reading. It is obligatory for them to learn. And the ability to read is obtained from learning. Even the Qur'an commands people to ask if they do not understand or do not know. ${ }^{2}$ It can be understood as a command for humans to learn so humans are needed to prepare learning facilities or equipment related to the intended learning. In addition, the most important is that they must prepare various teaching methods. In this case, Imam Bukhari described his opinion that learning is important until the end of life. Furthermore, Imam al-Ghazali firmly stated his opinion that learning is mandatory for every Muslim. ${ }^{3}$ It must be realized, not just as theory. Although the learning commands are general and do not mention a clear place of learning, the definition of learning in the Qur'an can be understood that:

Informal education, the mentioned education is in the household (Q.S. at-Tahrim [66]: 6).

In non-formal education, the community is required to form an organization that has the duty to carry out education so that its objectives are successful (Q.S. Ali 'Imran [3]: 104). Based on that basis, it can be understood that the importance of informal, formal and non-formal education as stated in the meaning of Q.S. Ali 'Imran [3]: 104 and Q.S. at-Tahrim [66]: 6. The understanding of lexical teaching as stated by Nana Sujana that teaching is a teaching and learning process which emphasizes more on the interaction between teachers and students through student learning activities and teacher teaching activities.

${ }^{2}$ Armen Mukhtar, “Konsep Pendidikan dalam Al-Qur'an”, Disertasi, IAIN Syarif Hidayatullah Jakarta, 1998, 36.

${ }^{3}$ Fatiyah Hasan Sulaiman, al-Marhab at-Tarbawiy inda al-Ghazali (Kairo: Maktabah Nahdhah, 1964), 6. 
The definition of effective teaching from H.C. Witherington and W.H. Burton Bapensi is very complex and depends on the integration of various factors. To find out some of the learning requirements, an investigation or research will be conducted to challenge all the components involved in a teaching process, both related to the teacher and those related to the students, or the existing methods. ${ }^{4}$

From some of the views from the experts mentioned above, it is possible that the writer has a little analysis that in the process, teaching focuses more on the teaching and learning process. In this case it will automatically direct students as objects. In this position, students will experience the learning process of acquiring teaching so the teaching and learning activities are the main core in the teaching and learning process. However, it should also be explained that not all teaching and learning activities are part of teaching because the learning activities can only be said to be a component of teaching when there is an interaction between educators and students and when the teaching process is taking place both in formal schools and in mosques (nonformal and informal).

\section{Education with Qur'anic Approach}

The word Qur'an means to collect and qora'a means to collect letters and words from one another (Q.S. al-Qiyamah [75]: 17-18). In reality, there are several views about the Qur'an. In fact, some scholars emphasize that the word AlQur'an is mashdar (like gerund; verb that is dotted) which is interpreted as isim maf' $u l$ namely maqru ', something that is read. Thus, qara'tubu, qur'an, qira'atan, wa qur'anan means the same as maqru '(which is read), then the name of Qur'an (recitation), namely isim maf'ul naming with isim mashdar.

${ }^{4}$ Wilbur Schramm, et al., Television in the Lives of Our Children (Stanford, California: Stanford University Press, 1976), 131. 
The Qur'an is devoted to the book which was revealed to the Prophet Muhammad so the Qur'an is the unique book's name. And in combination, that word is used for the name of the Qur'an as a whole, as well as the naming of the verses. So when someone hears people reading the Qur'anic verses, he is reading the Qur'an (Q.S. al-A'raf [7]: 204).

This book covers the core of God's books, even all knowledge. Qur'an is difficult to be constrained by logical definitions, which classify all types, parts and special provisions so that the definition of the Qur'an has really concrete limitations and definitions. That is presenting in the mind or reality as appointed as the Qur'an to the written to the Mushaf or read verbally. And some say that "the Qur'an is from Bismillahi al-rahmani al-rahim to the verse minal jinnati wa al-nas. Some scholars define the Qur'an (approaches its meaning and distinguishes it from others) as "Kalamullah" which was revealed to the Prophet Muhammad, for those who read it is worship. And limiting what is revealed is only "to Muhammad".

It means that it is not included in the previous Prophets, such as the Torah, Gospel, Zabur and others. Among those names are al-Kitab, al-Furqan, al-Dzikri and others. From above understanding, it is clear that the Qur'an is closely related to the world of education, because not only reading explicitly, but learning, understanding, researching and analyzing what is implied in the content of the verses that are read. Even the Qur'an that was first revealed is the command to read. It proves that Allah told humans to study. Therefore, Muslims for the past few centuries have been instructed to study and examine the verses of Allah, including nature and their bodies, so that they are not left behind by other more advanced and intelligent people who find science and technology because they study verses, then implement 
Qur'anic verse in their lives. Related to Qur'an and Hadith, Hadiths are all words, deeds, decrees and approval of the Prophet Muhammad which are made in the order or law in the religion of Islam. The hadith is used as a source of law in the religion of Islam besides the Qur'an, Ijma 'and Qiyas. The position of Hadith is the second source of law after the Qur'an. There are many scholars of Hadith narrators, but those who are often used as references for Hadith are seven scholars, namely Imam Bukhari, Imam Muslim, Imam Abu Daud, Imam Turmudzi, Imam Ahmad, Imam Nasa'i, and Imam Ibn Majah. The Hadith as the word of the Prophet explains the ijmal in the Qur'an. There are three functions of Sunnah or Hadith in Islamic teachings. First, it is as an explanation of the Qur'an.

If there are people who only use the Qur'an and do not want to use the Sunnah, then from where he knows that the zuhr prayer has four raka'ats. There is no information in the Qur'an regarding the zuhr prayer has four raka'ats, thawaf seven times and so on. There are two requirements of our worship accepted by Allah. Those are listed in the two words of syahadah. The first, there must be sincerity because of God, as stated in the tawheed creed, namely "I testify that there is no God but Allah". Secondly, the requirement is to follow the Prophet's guidance which is stated in the creed of the apostle, namely "I testify that Muhammad is the messenger of Allah".

Therefore, it is impossible for a Muslim to leave the Hadith. Second, the Hadith is as a supporter of the provisions in the Qur'an. For example, the Qur'an expressly forbids usury. Allah justifies buying and selling and forbids usury. Then the Hadith also forbids usury. Third, the Hadith is a source of Islamic law. The hadith is the second source of law after the Qur'an. Many Hadiths explain something 
that is not explained in the Qur'an. One of them is about being permitted to eat animal flesh called dlabb. Many people used to translate dlabb with monitor lizards, even though it turned out to be far different from monitor lizards because there were none in Indonesia. The determination of the halal of dlabb animals is based on the Prophet Hadith. So, the position and function of the Hadith is the second source of law after Qur'an. While its function is as an explanation, law reinforcement established in Qur'an, and as a source of independent law which is not explained in Qur'an.

\section{Educational Foundations in Qur'an Perspective}

The Qur'an asks people to always learn so they will have knowledge and it provides guidance in education so that humans can have knowledge in accordance with what is taught by the Qur'an. The Qur'an greatly distinguishes people who have knowledge with people who do not have knowledge (Q.S. az-Zumar [39]: 39). Then the Qur'an also mentions various creatures that live on this earth, so that humans use it and get lessons from the creation of Allah Almighty (Q.S. Fathir [35]: 12). Then Allah mentions these parables so that humans think and understand them, and take lessons from them to be used as signs of the greatness of God Almighty (Q.S. al-Ankabut [29]: 43).

Paying attention to the understanding of some above verses gives us an idea that knowledge of "al-'llm" is very important for humans. For that reason, humans are required to learn throughout their lives. The Qur'an gives the learning command for humans by starting "iqra" "/read. It includes reading the signs of Allah's greatness in this world. It is precisely that the Qur'an commands to ask people who are more skilled if they do not understand (Q.S. al-Nahl [16]: 43). In explaining the contents of the Qur'an through valid and muted hadiths, the prophet stressed the need for humans 
to follow education in order to gain knowledge; it can be seen in the Sabih al-Bukhari book, where al-Bukhari wrote specifically the need for knowledge and speaking before doing something. This is the importance of science that is found through education.

Therefore, almost all of the verses of the Qur'an provide a good education related to aqidah, shari'ah, and mu'amalah. Al-Qur'an and Hadith provide an explanation that education begins with a household. This is an obligation for humans to avoid the torments of hell fire as the word of God Almighty. (Q.S. at-Tahrim [66]: 6).

The meaning of that verse gives a signal to humans that the main place of education is starting from the household; the educators are mother and father because both of them are responsible at home. In addition, the family becomes a mirror in the general society behavior because the community is from the household, and if there is good education at home, the community will certainly feel their goodness.

The Qur'an further talks about the organization of education or institution that carries out education must function to call people to goodness and prevent evil (Q.S. Ali 'Imran [3]: 104). In that verse, Allah affirms to humans to make an organization or group having activity to ask people to goodness and have the ability to prevent all forms of evil. This is like giving a signal to humans to make groups, places, facilities that can invite people to prevent the evil, and groups that are able to carry out virtues in society.

The basis of education in Islam is the Qur'an. And the explanation of the meaning of Qur'an contents explained by the Qur'an itself is also the role of the Prophet hadith. It is very important because in the Qur'an, the Prophet Muhammad was the main educator and the Messenger of Allah. It can explain the content of the Qur'an in all aspects 
of human life so that the education in the Qur'an can be operationalized in human life to answer the challenges of the present and the future.

In terms of the excistence of the Qur'an, the first surab (Q.S. al-'Alaq [96]: 1-5) is about the education.

Recite in the name of your Lord who created, created man from a clot of congealed blood. Recite: and your Lord is Most Generous, Who taught by the pen, taught man what he did not know. (Q.S. al-'Alaq [96]: 1-5)

It is the magnitude of the Qur'an role in commanding people to read in order to have knowledge. Prophet Muhammad's Hadith also emphasized, "I have left two cases, if you hold them, it will not go astray forever." 5

\section{Role of Prophet Muhammad in Education}

The Messenger of Allah was the recipient of the revelation revealed by Allah Almighty. So, He gave explanations to the problem of human life through the interpretation of the Qur'an verses. For that reason, the Qur'an was made by the Messenger to be proof and explanation of all aspects of human life including solving educational problems.

Education is a very appropriate target for making individuals to be human beings who are noble, have dignity in their lives and lives. It is precisely that the Messenger of Allah carried out the education of the friends and Muslims, refined their behavior with Rida from Allah. The guidance and instructions of the Qur'an about education explain that the Messenger of Allah was a great and wise educator. Allah says in the Qur'an which means: " Just as We have sent among you a messenger from yourselves reciting to you Our verses and purifying you and teaching you the Book and wisdom and teaching you that which you did not know. So

\footnotetext{
${ }^{5}$ Muslim, Shabih Muslim (Mesir: Isa al-Babi al-Halabi, t.t.), Juz 2, 560.
} 
remember Me; I will remember you. And be grateful to Me and do not deny Me" (Surat al-Baqarah [2]: 151-152)

Allah explains that the role of the Messenger of Allah is as the main educator, as His words which means, There has certainly come to you a Messenger from among yourselves. Grievous to him is what you suffer; [he is] concerned over you and to the believers is kind and merciful.( QS at-Taubah [9]: 128).

In addition to the verse above, there are many more verses that explain the role of the Messenger of Allah in guiding, educating, and directing humanity to those that are accepted (get ridha) by God. The role of the Prophet in educating humans is carried out through words, deeds and through his provisions, as well as his very noble behavior. There will be no thing than can be same with the glory of the Prophet in educating human beings, the beautiful language art, the short but solid expression, and the intellectual, soul, and feelings power. Because of those points, the speech, language, sermon, invitation and decision of the Messenger was very right on his target. In the case of the language of the Prophet reviewed in terms of education, Sayyidah Aisyah R.A. said, "If the Messenger of Allah spoke, he did so with short and meaningful talks. If someone counts it, he speaks only one word, repeats the word three times so you can memorize it."

\section{Purpose of Education Based on the Qur'an Perspective}

The definition of purpose is the first component that must be established in the system of an educational institution. Objectives have a directional function to teaching and learning activities. The purpose of teaching is the formulation of behavior and abilities that must be achieved 
and should be possessed by students after completing learning activities. The contents of the teaching objectives are essentially expected learning outcomes. It has been popular that in education and teaching, there are goals that must be achieved. However, before the authors put forward the purpose of Islamic education, it will first address the general purpose of education. There are several purpose levels. Nana Sudjana divides the purpose into four levels, namely: (a) General purpose of education. In general, this educational goal is ranked at the top of all the objectives in this general objective including national goals. This national goal is stipulated by the government so the national goals of a country are not the same as other countries. These differences are in rhythm with the differences in the philosophical and political basis of each nation both in Islamic and western countries/non-Islamic countries; (b) Institutional objectives. This objective is expected to be achieved by the institution or type of school level as an intermediate goal to reach the general objectives. Therefore, the institutional objectives of the Primary School are different from the institutional objectives of Secondary and High School Secondary Schools even at the tertiary level. Each of these institutions has institutional objectives and leads to the general goals of education; (c) Curricular objectives. This curricular objective is the elaboration of the institutional objectives that contain educational programs in the curriculum of educational institutions. This goal describes students who have obtained education in fields of study taught in certain educational institutions. For example, the goals want to be achieved in PPKn or civic education, IPA or science, Arabic language and so on; (4) instructional objectives This is the lowest goal of the other objectives. 
Instructional objectives are the objectives that want to be achieved from each unit of study/each meeting/face to face of each subject. Instructional, curricular and constitutional objectives can be identified in the curriculum or the outline of the teaching program. Based on the classification of teaching objectives above, it can be seen that the purpose of Islamic education when it is viewed from the national goal is one element to realize national goals, especially those that can be related to the interests of the majority of the Indonesian population directly or indirectly. For example:

a. To make learning the Islamic teaching easier and according to the original source.

b. To foster Indonesian culture especially those relating to culture or Islamic culture

c. To build Indonesia where mastery of Islamic education is a spiritual aspect and can open new thoughts in a mental form that is useful for community / social life.

Some terms of educational objectives described above have relevance to the objectives of education in the Qur'an (Q.S. adz-Dzariyat [51]: 56). The aim achieved by reading, teaching, devoting as mentioned in the above verse is further explained by M. Quraish Shihab, namely as devotion to God in line with the purpose of human creation. Self-servitude to God as the goal of education has also been agreed upon by Islamic education experts in general. Muhammad Natsir stated that the purpose of man, to slave himself to Allah, means to be a servant of Allah and this is our goal in the world, which means that the goal of education must be given to children who are facing life.

The purpose of Islamic education formulated by Muhammad Natsir based on Q.S. adz-Dzariyat [51]: 56 above is also used as a benchmark by M. Quraish Shihab. However, the words "servitude to Me" in that verse has a very deep and 
broad, wider and deeper meaning than the words themselves that are spoken and used every day. Serving oneself to God includes all obedience and submission to all divine commands which carry the greatness of the world and the victory of the hereafter and abstain from all the prohibitions which obstruct the achievement the world and hereafter victory.

Thus, servitude to God can also be influenced by the arising of noble morality. That is why another formulation of educational goals as stated by Atiyah al-Abrasyi is to educate the morality and spirit of students, instill a sense of fadilab (virtue), familiarize them with high politeness, prepare them to have holistic, sincere, and honest life. On this basis, the main purpose of Islamic education is to educate character and spiritual. Athiyah further urged that all subjects must contain moral values. Every educator must think about religious morality before others, because noble morality is the pillar of Islamic education.

As explained above, Hasan Langgulung said that talking about educational goals cannot help us talk about the purpose of human life. This formula is based on a principle that education is only a tool used by humans to be able to maintain survival, both as individuals and as members of society. ${ }^{6}$ Based on Q.S. adz-Dzariyat [51]: 56 with various interpretations, it can be concluded that the purpose of Islamic education is to worship Allah in the broadest sense and reflected in the noble character in various activities of life.

\section{Educational Value in the Qur'an Perspective}

Educational material exemplified by the Prophet Muhammad generally is relevant to the word of God Almighty in Q.S. Luqman [31]: 13-19 that the value of

${ }^{6}$ Hasan Langgulung, Asas-asas Pendidikan Islam (Jakarta: Pustaka al-Husna, 1988), 305. 
education exemplified by the Prophet Muhammad based on the Qur'an includes five points. The first is monotheistic education. That is to instill in Allah as the One God. Allah is the only God to be worshiped. Worshipping the others is wrong and that is the act of shirk. And shirk is a big sin. The second is worship education. It includes praying and fasting. Third is courtesy and morality education. Fourth is physical education. And the last is social education (social life).

a. Taubid or Monotheistic Education

Related to monotheistic education, there are also many verses in the Qur'an that emphasize the importance of faith as the basis of the refusal of piety which will lead to peace of soul. Muhammad Abd Baqi 'mentioned that in the Qur'an, there are words of faith repeated more than 600 times in various forms.

Thus, faith according to education experts is a very important educational material. Therefore, the implementation is not only by memorizing the pillars of faith, knowing the obligatory, possible and impossible characters for Allah. But it can be done by fostering the students to have feeling of faith in Allah and love for mother, father, teacher and others. Furthermore, through the formation of faith above, the goodness and ethics are created. While, through the formation of human, knowledge will be got. Therefore, educational material must also be designed for intellectual development, such as learning to count, analyze, classify, conclude and so on so that they have thinking skills in problem solving. It is to move all concrete things to the senses and send impressions to the mind to get a concept formula of a particular problem. ${ }^{7}$

${ }^{7}$ Muhammad Quthb, Sistem Pendidikan Islam, terj. Salman Harun (Bandung: Alma'arif, 1984), 129. 
b. Physical Education

Through physical education, a skilled human will be created. In the Qur'an, the body is usually presented with the word jasad, and according to Muhammad Abd Baqi ', the word jasad in the Qur'an is repeated 4 times. Among them are in Q.S al-A'raf [7]: 148, Q.S. Thaha [20]: 88, Q.S. al-Anbiya [21]: 8, and Q.S. Shad [38]: 44.

In the four verses above, the word jasad is interpreted by the body in a physiological sense consisting of bones, flesh and so on. The parts of body are head, eyes, ears, nose, mouth, legs and others. The details are mentioned in a verse which means "they have eyes but not to see, and have ears but do not use them to hear, they are like animals even worse than that. They are people who are negligent (Q.S. al-A'raf [7]: 179).

The verse mentions jasad as physical parts physiologically and also mentions its psychological function. It gives a signal that the body needs to be well educated so that it can carry out its functions well and productively. Furthermore, it can be done by providing physical education material in the form of athletics and games with tools and others.

The Prophet's Hadith mentions that some of the ways are: "Exercise archery, wrestle, run, race and swim". The hadith is an educational material that was once recommended by the Messenger of Allah. We must apply it in this life.

c. Worship Education

\section{1) Prayer}

The prophet of Allah at Anas r.a house did worship with Anas family. It illustrates how much the prophet cares about the education in the household and the prophet of Allah cleanses the rug. This is a portrait that the prophet educated intellectuals and also foster cleanliness to students. 
Based on the explanation above, it can be said how great the attention of the prophet of Allah towards education for children. This is certainly based on the nature of the prophet of Allah who was full of compassion, always maintaining cleanliness, patience in dealing with problems, the furthest from the nature of despair, so that The Qur'an contributes to the nobility of the Prophet. All the noble morality is found in the prophet of Allah, and the Prophet's noble morality must be followed by educators

They are the messangers' characters in Torah and Gospel. The verse above gives a signal to humans that the face of the prophet of Allah and those with him are always beaming and they always love. The Qur'an educates humans especially through worship. The service offered by the Qur'an to educate humans is the worship of prayer, after the Qur'an describes the aqeedah as the basis for human beings to carry out worship. It suggests humans that in prayer, there are all kinds of success that will be achieved by humans and contained in the prayer referred to spiritual and physical, patience, discipline education, and thinking education through the recitation of prayer.

Muhammad Abduh argued that prayer does not only function to protect the doer (al-mushallin) from all evil deeds, but that prayer should encourage people to do goodness to others. This is seen once when Muhammad Abduh interpreted the word of Allah Almighty in Q.S. al-Ma'un [107]: 4-7. In the interpretation of the verse, Muhammad Abduh stated, "Those who neglect prayer are those who actually perform prayers, but not motivated to practice charity sincerely. They do good deeds (solely with the motive of wanting to be seen by humans), they are reluctant to set aside some of their wealth for helping and encouraging others. There is no affection in their hearts to meet the needs of others so that 
they feel the happiness and tranquility of life. The prayers they are working on are obviously not useful to them and do not exclude them from the deniers of religion "(Q.S. alMa'un [107]: 4-7).

Muhammad Abduh stressed that prayer is not useful for the doer if he cannot have good morality. People a prayer should do goodness easily for themselves and for others, and avoid the despicable nature, moral deeds, and other evil deeds. According to Muhammad Abduh, if someone's prayer does not prevent him from doing evil does not eliminate anxiety and does not erode the evil and the nature of greed, so he is not a person who performs the prayer as mentioned in the Qur'an.

Based on Muhammad Abduh's interpretation of the prayer verses, there is a very great moral education to deal with all kinds of things that will disrupt and destroy the values of life, so that the prayer makes a devoted man in his life. To find moral values that can educate humans contained in the Shari'a of Worship, it is very necessary to have the ability to think and an in-depth analyst about the Qur'an. To find the wisdom and value of worship as a means of education, it needs discussion of "al-bahs" or the sciences of thinking analysis "al-ilm al-nazhari" or a rational conversation (al-kalam al-ma'qul). Interpretation that successfully explains the wisdoms of worship and the moral messages contained are interpretations that have a high element of rationality because basically, the interpretation is meant to talk about things that refer to the multiplication of the meanings of the philosophy of religion itself. So, through interpretation, secret and wisdom is commanded of worship to humans will be revealed.

Prayers are commanded in the Qur'an and contain elements of high moral education. Among the various forms 
of worship that are commanded by the Qur'an, prayer is the most strategic worship to bring people to feel close to their God. In human, a person who prays as if he has a dialogue and approaching, whispering, having a degree, and asking sincerely to God. That act is carried out full of humility, blessings, and tawadhu 'as if dealing with God.

In prayer, human perform active readings and movements governed by God, such as being holy to God, surrendering to Him, asking to be protected by God, asking for His forgiveness, asking for guidance on the right path and being given forgiveness and ability to do what the best in this life, and not the way of people wrathed nor the way of people who are astray. Humans who pray are asking God for the soul purified by God, so that they tend to do goodness and praise and be blessed by Allah in his life. In fact, it is very precise and strategic. This prayer service is a powerful way in educating humans.

In the prayer, the Qur'an explains repeatedly that it is sometimes associated with zakat, command of amar makruf nabi mungkar, and qurban worship. It gives a signal to humans that the prayer service is aimed not only at the relationship with God, but emphasizes again to always be good with other human beings. Through prayer, there is a solid relationship between the creatures and the creator.

The education contained in the prayer is not in the sinful deeds, but it is the holy soul of the people who pray to do goodness. And the prayer prevents them from being cruel and evil (not pleased by God Almighty). It informs people that if someone is diligent in praying, but his soul is not pure, malicious, jealous, hypocritical, greedy, and other bad characters, he has not got the benefit yet from his prayer.

The prayers received by Allah are prayers that make the doers free from bad things, not arrogant, low self-esteem, 
always remember God, have a sense of social care to help those who need it, such as the poor and people who got the disaster, etc. This is in accordance with the affirmation of the hadith Qudsi, "Prayers that I (Allah) receive are prayers that make the perpetrators humble themselves towards My Greatness, do not against My creatures, do not always do evil to disobey me, but always remember me and give love to the poor, people who are displaced in the journey, women with his husband passed away, and love those who are afflicted by calamity ".

Emphasis on education in prayer is is seen in the discipline, sincerity and its role in preventing the perpetrator from doing what Allah forbids, so that it is hoped that the person who is praying becomes a person who is good for Allah in his life. This is also in line with the purpose wanted to be reached in the Qur'an. According to the opinion of Muhammad Abduh, prayers carried out in an order and correct manner are prayers that produce wisdom because God commands people to pray in the Qur'an by the term "iqamah ash-shalah" to establish prayers. This is interpreted by Muhammad Abduh: "Doing prayer by presenting the heart before the majesty of God, accompanied by khuss' is not merely a physical movement because movements in prayer are not at all the essence of prayer.

In the prayer service, it is expected that a servant is expected to be able to live as deeply as the presence and greatness of God in this life, as if he sees Him, and even if he could not see Him, then God could see it. In this point, Muhammad Abduh stressed again that physical movements or attitudes in prayers such as, ruku' and sujud on the ground surface (the place of prayer) are intended to remind the forgetful servant and encourage him to show complete obedience and submission to the Supreme Lord. 
It is appropriate to say that the perfect prayer is prayer done solemnly 'and the presence of a heart that is accompanied by the "thuma'ninah" calmness of all the limbs. In its affirmation, the words from Ali Ahmad al-jurjawi are very perfect. So the Qur'anic command about prayer with the term "iqamah al-shalah" and reviewed by Muhammad Abduh is very precise because the prayer like this can form a sense of religion or high religiosity and feeling will prevent someone from being evil, and of course a high sense of religiosity can have very broad implications in his life.

Due to the calmness of the soul produced through communication with God in prayer, those who pray obediently and solemnly will have a more balanced, hopeful and not self-conscious or arrogant soul. And in this life, they do not complain when calamity is over, and not also stingy if they get good luck in his life.

Based on the explanation of prayer lessons mentioned above, it can be stated that in prayer, there is education that is closely related to the determination of the soul and patience in all things and feels that life is in God's protection because God always gives sustenance and nurtures all His creatures, so that people feel safe and secure. It is the main capital in manifesting a moral life towards the pleasure of Allah.

This can be seen from the content of Muhammad Abduh's previous interpretation that if prayers cannot create the high social awareness and are not able to erode the bad things, do not care about the fate of the poor, not the prayers outlined in the Qur'an, and such prayers will lose the meaning of prayer which is essential. Finally, the doer has no right to get and receive what Allah has promised in the Qur'an for those who pray, such as happiness of life, soul peace, determination of faith and glory from God. 


\section{2) Fasting}

Al-Qur'an educates humans through the firm of God Almighty who deals with worship in particular, so fasting has a big contribution in educating and guiding humans so that fasting contains the values of education.

Fasting plays a role in educating the human soul and creating a pure soul and farthest from the nature of defilements. To treat the soul of various spiritual ailments, fasting gives a very large role so that the person who fasts with full awareness and calculation in the implementation will receive soul peace and forgiveness of his sins. The essence of the command to fasting is a formidable educational means, especially in self-control. Seeing the verse about the command of fasting mentioned above, Muhammad Abduh gave a shara understanding that fasting is not eating and drinking and not intercourse with wife start from dawn till maghrib (sunset). The fasting person hopes Allah will redeem and educate the soul to be more cautious by getting closer to God. And it can educate the will (al-iradah) through restraint of lust in order to get the ability and resilience to leave things that are forbidden.

In this case, the greatest wisdom of fasting is selfcontrol, as Dadang Hawari explained that self-control is one of the main characteristics for healthy people and when one's self-control is disturbed, it will cause various abnormalities (pathological) whether it is in the mind, nature feelings or behavior. The pathological reaction caused not only causes subjective complaints on him but also can interfere with the environment and also other people. For example, people who do not have self-control about and drink, the person will experience obesity and will also experience various complications obesity. Today, many diseases are caused by too much eating, many substances exchange (metabolism) as 
a result of excess food. Carrying out the fasting month of Ramadan is the best way for humans to control themselves, recognizing the mercy of God which is bestowed upon him, where in the month of Ramadan, the Qur'an is revealed as a guide to human life. Fasting educates humans voluntarily and sincerely leaves various pleasures such as intercourse with wives during the day, eating and drinking, curbing lust, greed, lying, betrayal, hasad, scandalous, berating others, extravagant and addictive doing fasting clearly the most powerful means to educate yourself and the human soul to discipline like breaking the fast in time to slow down eating sahur, of course it is clear to draw closer to God physically and spiritually.

Fasting as an educator can be explained by Muhammad Abduh in the hadith of Prophet as a protective device (Junnah wa al-wiqayah) guarding the doer (al-qa'im) from all kinds of immoral acts and sins that will make them go to hell. One of self-control in educating humans in this fasting month is controlling lust. People who are not fasting, especially self-control in the sexual point will show deviant sexual behavior, such as abuse, promiscuity and a domestic crisis, the spread of venereal disease and the development of greed, voraciousness, cannot distinguish halal haram, acts of corruption and misappropriation and seize the rights of others. The impact of this lack of self-control will be detrimental to someone and in turn will destroy the social values of people's lives and of course the gulf of destruction will hit the community.

The command of fasting is an exercise in self-control education, so that humans have a healthy and strong soul, and strengthen faith and devotion to Allah Almighty. And it can avoid doing actions that violate ethics, morals and law. The Messenger of Allah stated in the hadith, "Fasting is not 
just to refrain from eating and drinking, but the fasting is to prevent you from all futile deeds and stay away from bad and cruel acts."

From the sign of the hadith, it is clear to us that fasting is a powerful and very rational means of mental education when it is linked to the reality of a dynamic community life. The question arises: can fasting prevent mental disorders? The mental disorder meant here is a non-psychic mental disorder, which is a type of mental disorder in which a person still has a good awareness or understanding, but unable to prevent it, namely mental disorders, phobias, obsessions and compulsions, to overcome illness phobias, obsessions, compulsions. Fasting is able to reassure the soul. People who have this mental disorder, the Qur'an treat and revive and reassure their souls, awaken their souls and prevent them from having a mental disorder that troubles their lives. This is in accordance with the word of God Almighty in Q.S. alHadid [57]: 20, Q.S. al-Ma'arij [70]: 21-24, and Q.S. al-A'la [87]: 14-17.

Related to this verse, the explanation is as follows: Phobia is irrational and realistic fear. The person affected by this mental disorder knows and is well aware of his irrationality and dishonesty, but he is unable to prevent and control himself from his "fear". As for "Obsession", it is a persistent and recurrent pattern of thought in which the person knows correctly about the thought disorder, but is unable to divert his mind to this matter and is unable to divert his mind to other things and unable to prevent the emergence of those thoughts which always arise again and again. Whereas "Compulsion" is a pattern of repeated actions in which the person knows well that the act of repeating is not true and irrational, but he is unable to prevent his own actions. 
As an example of mental disorders "Obsession" and "Compulsion" can be seen in society. For example, people who seek property, rank, position, world life, even by using any ways, stealing, corruption, lying, hasad, greed, greedy and others. He knows that these qualities are not good and despicable and hated by religion and government, but he still does it repeatedly consciously and rationally. Eventhough his mind is haunted by fear, God's threat, sin and punishment to him, his mind was unable to prevent him so that he felt a long fear but could not stop his actions. People like this suspect that the pleasures of life can only be guaranteed by wealth, title and position, but he is unable to divert his mind to others.

\section{Conclusion}

It can be concluded that the integration of moral and science in the perspective of qur'ani education, among others, is determined and lies in the placement of religious law and philosophy. The philosophy of education in an Islamic perspective provides a strong foundation for the nature of human creation as a caliph on earth. This proper understanding of human nature qur'ani is used as the basis of philosophy in formulating and realizing the goals of Islamic education. The value in the shar'i procedure in the Qur'an is placed in achieving the virtue and glory of life. Teaching aim is to empower the potential of the human mind which functions for the purpose of understanding and studying religious shari'a in its application, so that education that forms morality and science-oriented teaching can be realized to form a disaffected Muslim personality.

The Prophet Muhmmad is the perfect example of the teacher to carry out the functions of education and teaching. We can find moral values from the Messenger of Allah and 
he was sent to this earth to improve morals. The Qur'an expresses education and teaching especially through morality to God by carrying out orders and staying away from His prohibitions, and morality to humans through good manners. In whatever situation and condition, someone is able to provide direction, educate and teach humans to the true path of life happiness. 


\section{REFERENCES}

Alavi, M. Ziauddin. Muslim Educational through in the Middle Ages. New Delhi: Atlantics Publishers and Distributors, 1988.

al-Attas, Muhammad Naquib. Konsep Pendidikan dalam Islam, translated by Haidar Bagir. Bandung: Mizan, 1984.

Daradjat, Zakiah. Membina Nilai-nilai Moral di Indonesia. Jakarta: Bulan Bintang, 1976.

Echols, John M. and Hassan Shadily, Kamus Inggris-Indonesia. Jakarta: Gramedia, 1982.

Howe, Michael. Learning in Infants and Young Children. Stanford, California: Stanford University Press, 1975.

Hs., Fahruddin. Ensiklopedi Al-Qur'an. Jakarta: Rineka Cipta, 1965.

Ja'far, M. Beberapa Aspek Pendidikan Islam. Surabaya: al-Ikhlas, 1982.

Langgulung, Hasan. Asas-asas Pendidikan Islam. Jakarta: Pustaka al-Husna, 1988.

Madjid, Nurcholish. Masyarakat Religius: Membumikan Nilai-nilai Islam dalam Kebidupan Masyarakat. Jakarta: Paramadina, 1997.

Marimba, Ahmad D. Pengantar Pendidikan Islam. Bandung: Alma'arif, 1984.

Mirza, Muhammad R. and Muhammad Iqbal Siddiqi (ed.). Muslim Contribution to Sciane. Lahore: Kazi Publications, 1986.

Mukhtar, Armen. "Konsep Pendidikan dalam Al-Qur'an", Disertasi, IAIN Syarif Hidayatullah Jakarta, 1998. 
Mursa, Muhammad Munir. At-Tarbiyah al-Islamiyyah: Ushuluba wa Tathawnuruba fi al-Bilad al-'Arabiyyah. Kairo: 'Alam al-Kutub, 1977.

Muslim. Shabih Muslim. Mesir: Isa al-Babi al-Halabi, n.y.

an-Nahlawi, Abdurrahan. Ushul aT-Tarbiyah al-Islamiyah wa Asalibuha fi Labayt wa al-Madrasah wa al-Mujtama'. Damaskus: Dar al-Fikr, 1979.

Naqawi, Sayyid Khadim Husayn. Dictionary of Islamic Terms. No publisher, 1992.

Poeradisastra. Sumbangan Islam terhadap Peradaban Dunia. Jakarta: UI Press, 1978.

Poerwadarminta, W.J.S. Kamus Umum Bahasa Indonesia. Jakarta: Balai Pustaka, 1993.

Quthb, Muhammad. Sistem Pendidikan Islam, terj. Salaman Harun. Bandung: Alma'arif, 1984.

Rakhmat, Jalaluddin. Psikologi Komunikasi. Bandung: Remaja Rosdakarya, 1986.

Saruji, Majdag Hanusy. Thuruq at-Ta'lim fi al-Islam. Mesir: Mathba'ah Dar al-Masyriq li at-Tarjamah wa athThaba'ah wa an-Nasyr, 1992.

Sarwono, Sarlito Wirawan. Pengantar Umum Psikologi. Jakarta: Bulan Bintang, 1996.

Schramm, Wilbur, et al. Television in the Lives of Our Children. Stanford, California: Stanford University Press, 1976.

Sears, Robert R., et al. Patterns of Child Reaning. Stanford, California: Stanford University Press, 1976.

Shihab, M. Quraish. Membumikan Al-Qur'an: Fungsi dan Peran Wabyu dalam Kehidupan Masyarakat. Bandung: Mizan, 1991.

Sulaiman, Fatiyah Hasan. al-Mazhab at-Tarbawiy inda alGhazali. Kairo: Maktabah Nahdhah, 1964. 
Suryapratondo, Suparlan. Ilmu Jiwa Kepribadian. Jakarta: Paryu Barkah, 1982.

Ulwan, Abdullah Nasih. Tarbiyah al-Aulad fi al-Islam. Beirut: Dar as-Salam, 1978.

Wehr, Hans. A Dictionary of Modern Written Arabic. Ithaca: Cornell University Press, 1996. 